\title{
Hypermethylation of EDNRB promoter contributes to the risk of colorectal cancer
}

\author{
Cheng Chen ${ }^{1,2}$, Lingyan Wang ${ }^{3}$, Qi Liao ${ }^{1}$, Yi Huang ${ }^{4}$, Huadan Ye ${ }^{1}$, Fei Chen ${ }^{1}$, Leiting Xu ${ }^{1}$, Meng Ye ${ }^{2^{*}}$
} and Shiwei Duan ${ }^{1 *}$

\begin{abstract}
Objective: Colorectal cancer (CRC) is one of the most common digestive malignancies in the world. EDNRB is a new candidate tumor suppressor gene which is often down-regulated or even silenced by promoter hypermethylation in various human cancers. However, the function of EDNRB gene in CRC remains unknown. In this study, we examined the expression and DNA methylation of EDNRB in CRC tissues.
\end{abstract}

Methods: A total of 42 paired CRC and adjacent normal tissue samples were used to determine mRNA levels and DNA methylation status of EDNRB gene by qRT-PCR and methylation-specific PCR (MSP), respectively.

Results: Our study showed that EDNRB promoter hypermethylation was more frequently in CRC tissues than in the normal tissues (92.86 versus 59.52, $p=0.001$ ). Consequently, significantly lower level of EDNRB mRNA was found in CRC tumor samples than in normal samples $(0.31 \pm 0.91$ versus $0.70 \pm 1.18, p=0.032)$.

Conclusions: Our results suggested that EDNRB promoter hypermethylation might downregulate its gene expression in CRC, and thus played an important role in the development of CRC.

The virtual slide: The virtual slides for this article can be found here: http://www.diagnosticpathology.diagnomx.eu/vs/ 7420980471113303

Keywords: Colorectal cancer, EDNRB, DNA methylation, Biomarker

\section{Introduction}

Colorectal cancer (CRC) is a malignant disease caused by a variety of factors involving with the accumulation of genetic and epigenetic changes. The incidence of CRC is increasing rapidly, and there are 1 million new CRC cases annually [1]. In the developed countries, the mortality of CRC has soared up to 33. CRC has become the second most common cancer in the world [2], accounting for 9 of all malignant tumors deaths [3]. Although 5year survival rate of CRC patients has been improved from 22 to 47 in the last 30 years due to the advancement of the early diagnosis, surgical techniques and adjuvant therapies, the overall survival rate remains disappointing.

\footnotetext{
* Correspondence: yemeng@nbu.edu.cn; duanshiwei@nbu.edu.cn

${ }^{2}$ The Affiliated Hospital, Ningbo University, Ningbo, Zhejiang 315000, China 'Zhejiang Provincial Key Laboratory of Pathophysiology, School of Medicine, Ningbo University, Ningbo, Zhejiang 315211, China

Full list of author information is available at the end of the article
}

Abberrant expression of some important genes, such as beta-catenin [4], SATB1 [5] and EGFR [6], were shown to be significantly associated with the occurrence and prognosis of CRC. Gene promoter hypermethylation often silences gene expression, while promoter hypomethylation tends to activate gene transcription. DNA methylation alteration has been considered as an important event in many malignancies including CRC.

Endothelin receptor type $\mathrm{B}(E D N R B)$ gene is located on 13q22, encoding a nonselective endothelin $B$ receptor $\left(E T_{B} R\right)$ which belongs to a super-family of G-protein coupled receptor that mediates endothelins (ETs) [7]. $\mathrm{ET}_{\mathrm{B}} \mathrm{R}$ is able to promote the production of neural crest cell-specific lineage, and thus it is related to the occurrence of Hirschsprung's disease [8] that is a blockage in the colon.

There are massive CPG dinucleotide repeats in the $5^{\prime}$ flanking region of $E D N R B$ gene. The methylation of this CpG-riched region was shown to be able to regulate EDNRB gene expression [9-11]. Hypermethylation of 
$E D N R B$ gene promoter has been observed in leukemia [12], oral cancer [13], skin cancer [14], head and neck cancer [15], melanoma [16], renal cell carcinoma [17], bladder cancer [18] and prostate cancer [19]. However, the function of $E D N R B$ gene in CRC remains unknown. In light of previous findings in various cancers, we investigate whether $E D N R B$ gene promoter methylation contributes to the risk of CRC in Chinese population.

\section{Materials and methods}

\section{Tissue samples collection}

Tumor and its normal adjacent tissue samples were collected at the time of surgery from 42 primary sporadic CRC patients in the Department of Gastrointestinal Surgery in Affiliated Hospital of Ningbo University between June 2012 and April 2013. Normal adjacent tissues were collected at least $5 \mathrm{~cm}$ away from the tumor. Tissues were stored in liquid nitrogen at $-80^{\circ} \mathrm{C}$ immediately after excision. The diagnoses of all CRC cases were pathologically confirmed. None of CRC patients had received preoperative chemotherapy or radiation therapy. Tumor stage was determined according to the Duke's staging system, and cellular differentiation was graded according to the Broders' grading system. All the patients in the study have signed the informed written consent forms.

\section{DNA isolation}

Genomic DNA from tissue samples were extracted with QIAamp DNA Mini Kit (Qiagen, Hilden, Germany) according to the manufacturer's instruction. Briefly, tissue sections were incubated with $180 \mu \mathrm{l}$ of buffer ATL (in QIAamp DNA Mini Kit) and $20 \mu \mathrm{l}$ of proteinase $\mathrm{K}$ on a thermostatic water bath at $56^{\circ} \mathrm{C}$ for $3 \mathrm{~h}$, followed by incubation at $70^{\circ} \mathrm{C}$ for $10 \mathrm{~min}$. Then, $200 \mu \mathrm{l}$ of remixed Buffer AL (in QIAamp DNA Mini Kit) and ethanol (ratio 1:1) were added. Samples were mixed and transferred into QIAamp Mini spin columns. Centrifugation at $8,000 \mathrm{rpm}$ for $1 \mathrm{~min}$ was followed by washing the spin column membrane with $500 \mu \mathrm{l}$ of Buffer AW1 and $500 \mu \mathrm{l}$ of Buffer AW2. DNA was eluted with $100 \mu \mathrm{l}$ of Buffer AE. DNA concentration and quality were determined with spectrophotometer.

\section{Bisulfite modification}

Eluted DNA was bisulphite-treated with ZYMO EZ DNA Methylation-Gold Kit according to the manufacturer's instruction (Zymo Research, Orange, CA, USA). The bisulphite-modified DNA was resuspended in $10 \mu \mathrm{l}$ of TE buffer.

\section{Methylation-specific PCR (MSP)}

Methylation status of $E D N R B$ promoter was determined by MSP. For the PCR reaction, $2 \mu \mathrm{l}$ of modified DNA was amplified in a $20 \mu \mathrm{l}$ reaction containing $0.3 \mu \mathrm{M}$ each of forward and reverse primers, $0.2 \mathrm{mM}$ dNTPs, $10 \times$ PCR Buffer and 2.5 U of Hot Start DNA Polymerase (Qiagen, Hilden, Germany) under the following conditions: $15 \mathrm{~min}$ of denaturation at $95^{\circ} \mathrm{C}$ followed by $35 \mathrm{cy}-$ cles of $45 \mathrm{~s}$ at $94^{\circ} \mathrm{C}, 45 \mathrm{~s}$ at $62^{\circ} \mathrm{C}$ for methylated primers, $1 \mathrm{~min}$ at $72^{\circ} \mathrm{C}$ and a final extension for $10 \mathrm{~min}$ at $72^{\circ} \mathrm{C}$. The sequences of methylated and unmethylated primers were given in the previous study [20] (Table 1). Water blank was used as a negative control. PCR products were subjected to 2.0 agarose gel electrophoresis at $100 \mathrm{~V}$ for $20 \mathrm{~min}$, and visualized directly under UV illumination. Samples were considered as methylation or unmethylation, when there were clearly visible bands (130 or $134 \mathrm{bp}$ ) on the gel for methylation or unmethylation primers.

\section{RNA isolation and reverse transcription}

Total RNA was extracted from fresh frozen CRC and normal tissues from the same patients. RNA was extracted with TRIZOL reagent (Invitrogen Life Technologies Co, USA) according to the manufacturer's protocol. RNA concentration and quality were determined by NanoDrop ND-1000 (Thermal Fisher Scientific, USA). The first-strand cDNA was synthesized according to the manufacturer's instruction of M-MLV Reverse Transcriptase (Promega, Wisconsin, USA) with $2 \mu \mathrm{g}$ DNase I-treated total RNA and $2 \mu \mathrm{M}$ Oligo $(\mathrm{dT})_{15}$ primer in a $20 \mu \mathrm{L}$ volume.

\section{qRT-PCR}

Primers for qRT-PCR were listed in Table 1 [21]. The qRT-PCR reactions were conducted in a 96-well plate using ABI7500 Real-Time system (Applied Biosystems, CA, USA). Each reaction was performed in triplicate and in a $20 \mu \mathrm{L}$ volume containing $2 \times$ real-time PCR Master Mix with SYBR Green dye (Promega, Wisconsin, USA), $0.4 \mu \mathrm{M}$ of each primer and $4 \mu \mathrm{L} \mathrm{cDNA}$, using the

Table 1 List of all primers used and conditions of PCR amplification

\begin{tabular}{|c|c|c|c|}
\hline & Primer & Sequence $\left(5^{\prime}-3^{\prime}\right)$ & $\begin{array}{l}\text { Product } \\
\text { size (bp) }\end{array}$ \\
\hline \multirow[t]{2}{*}{ M } & $\mathrm{F}$ & CGAAGAGGTTGCGGGCGGTATTAGCG & 130 \\
\hline & $\mathrm{R}$ & TACTCCAAAAACGTCCGATAACCG & \\
\hline \multirow[t]{2}{*}{$U$} & $\mathrm{~F}$ & TGGTGAAGAGGTTGTGGGTGGTATTAGTG & 134 \\
\hline & $\mathrm{R}$ & ACCTACTCCAAAAACATCCAATAACCA & \\
\hline \multicolumn{4}{|c|}{ RT-PCR } \\
\hline & EDNRB-F & GAAAGCCTCCGTGGGAATC & 86 \\
\hline & EDNRB-R & ACAGCTCGATATCTGTCAATACTCAGA & \\
\hline & GAPDH-F & CCATGGAGAAGGCTGGGG & 194 \\
\hline & GAPDH-R & CAAAGTTGTCATGGATGACC & \\
\hline
\end{tabular}


following thermal conditions: $95^{\circ} \mathrm{C}$ for $10 \mathrm{~min}$, followed by 40 cycles of $95^{\circ} \mathrm{C}$ for $15 \mathrm{~s}, 60^{\circ} \mathrm{C}$ for $1 \mathrm{~min}$ and $72^{\circ} \mathrm{C}$ for $40 \mathrm{~s}$. A melting curve analysis from $60^{\circ} \mathrm{C}$ to $95^{\circ} \mathrm{C}$ was performed at the end of each PCR to further confirm the specificity of amplicons. GAPDH was used as an endogenous control. The Ct values displayed by the instrument were recorded. Samples were confirmed whether there was a clearly visible band (86/194 bp) on the gel with $E D N R B$ or GAPDH primers (Figure 1).

\section{Statistics}

Statistical analysis was performed by the SPSS statistical package (version 16.0; SPSS, Chicago, IL, USA) and the results were presented using GraphPad prism software. Comparisons of $E D N R B$ promoter methylation were performed by the correction formula of Chi-square test. The $2^{-\Delta \mathrm{Ct}}$ method was used to analyze the result of qRT-PCR. Two groups of related data were analyzed using paired t-test. The Mann-Whiteney $U$ test was used for two groups of independent data which did not meet

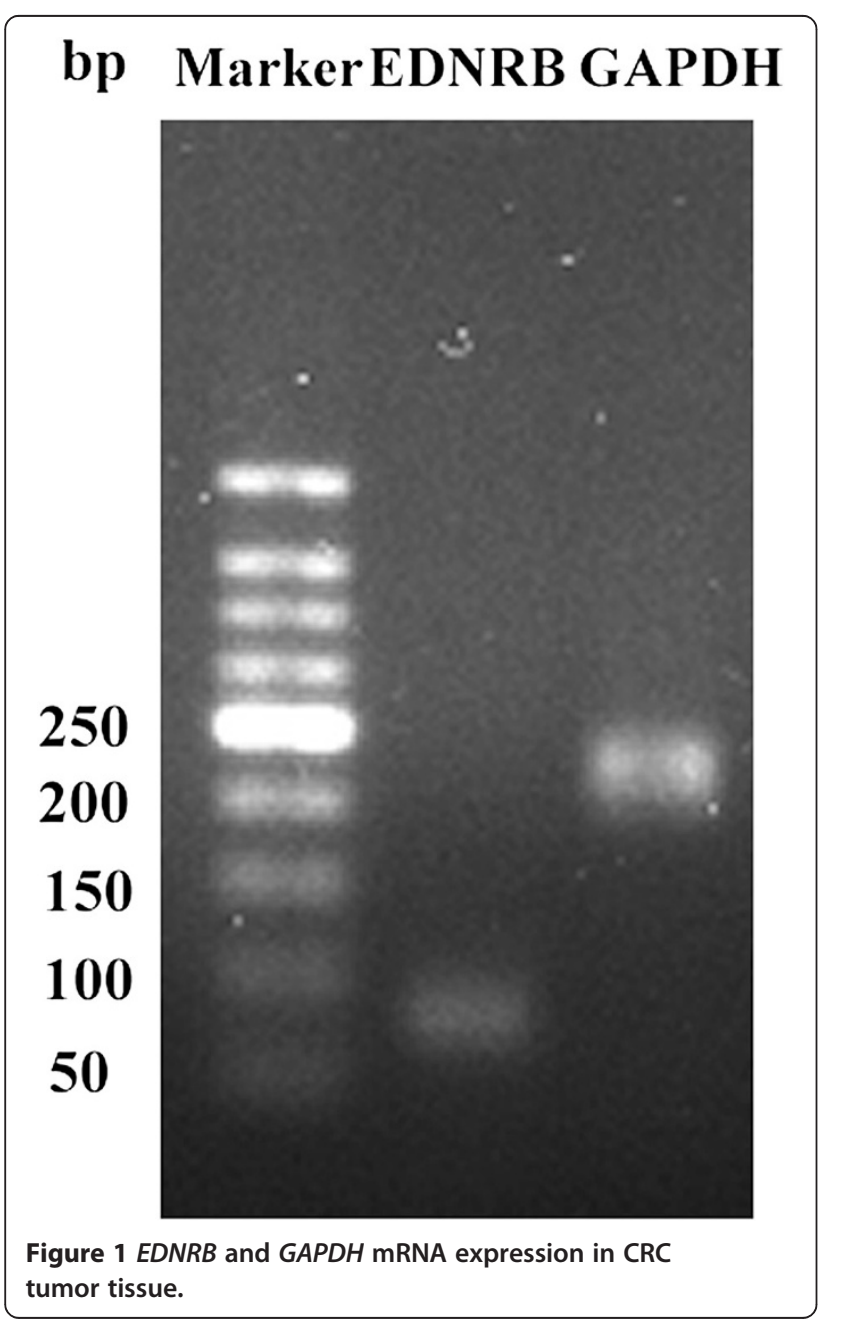

normality test. All analyses were two-sided, and $\mathrm{p}<0.05$ was considered statistically significant.

\section{Results}

Hypermethylated EDNRB promoter in CRC

To determine methylation of EDNRB gene, MSP was performed on $42 \mathrm{CRC}$ and 42 adjacent normal tissues in the primary sporadic CRC patients. The representative agarose gel electrophoresis results were shown in Figure 2. Methylation status was determined when there were methylated bands in the gel. And unmethylation status was determined if both the methylated and unmethylated bands were not detected, For the unmethylated samples, we repeated the relative experiment two times, including testing the DNA quality, bisulphite modification and MSP (confirming PCR primers quality and PCR conditions). If the methylated and unmethylated bands still did not detect, we confirmed the status of the sample as unmethylation. Our study showed that hypermethylation of EDNRB in CRC tissues was more frequently than in corresponding normal tissues (92.86 versus 59.52, $\mathrm{p}=0.001$, Table 2 ).

\section{Correlation of EDNRB methylation with clinicopathological characteristics}

The relationship between methylation status of $E D N R B$ gene and the clinicopathological characteristics of CRC was shown in Table 3. There was no significant difference in clinicopathological factors such as gender, age, TNM stages, lymph node status, metastasis status, tumor location, differentiation status, tumor size, and histological grade. There was no correlation of EDNRB gene methylation status with the serum levels of carcinoembryonic antigen (CEA) and carbohydrate antigen 19-9 (CA19-9).

\section{EDNRB expression is down-regulated in CRC tissues}

We determined EDNRB mRNA expression in 42 CRC tissues and 42 adjacent normal colorectal tissues by qRT-PCR. The gene expression level of $E D N R B$ was normalized with the values of the control gene GAPDH. Our results showed that EDNRB mRNA level in CRC tumor samples was significantly lower than in their adjacent normal samples $(0.31 \pm 0.91$ versus $0.70 \pm 1.18, \mathrm{p}=0.032$, Figure 3, Table 4).

\section{Correlation of EDNRB expression status with clinicopathological characteristics}

We further examined the relationship between EDNRB mRNA expression and clinicopathological characteristics (Table 5). There was no significant correlation between $E D N R B$ expression and the clinicopathological factors such as gender, age, TNM stages, lymph node status, metastasis status, tumor location, differentiation status, tumor size, and histological classification. 


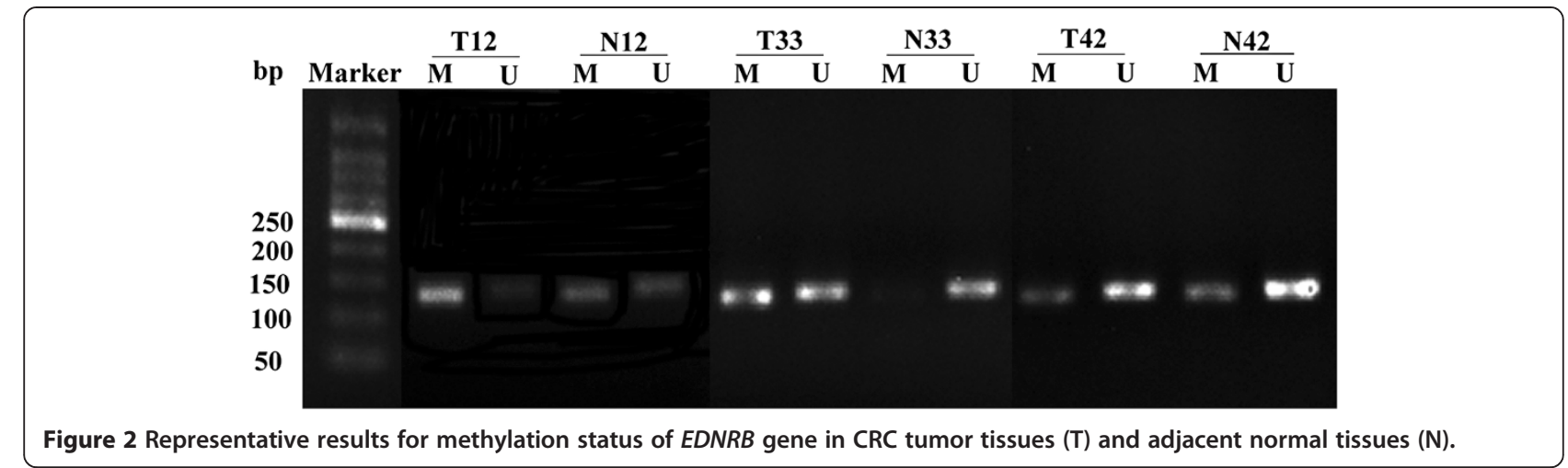

\section{Discussion}

Cancer development and progression may be contributed by both genetic and epigenetic factors. As one of the major epigenetic modifications, DNA methylation of promoter often down-regulates gene transcription. A growing number of evidences show that DNA methylation mediated tumor suppressor gene silencing may contribute to tumor progression [22-24]. Aberrant DNA methylated loci have become promising biomarkers in the early diagnosis of diseases [25,26].

EDNRB is a G protein-coupled receptor that activates a phosphatidylinositol-calcium second messenger system. The product of $E D N R B$ gene $\left(\mathrm{ET}_{\mathrm{B}}\right.$ receptor, $\left.\mathrm{ET}_{\mathrm{B}} \mathrm{R}\right)$ is able to bind to endothelins (ETs), consisting of a family of 3 potent vasoactive peptides (ET1, ET2, and ET3) [13]. During the development of tumor, EDNRB gene transcription is downregulated by promoter hypermethylated, and consequently alters the ET1 signaling pathway [27]. Disruption in the ET1 signaling pathway has been shown to be involved in a variety of human tumor proliferation, angiogenesis, and metastasis [28-30]. EDNRB gene silencing by promoter hypermethylation has been reported in a variety of tumors such as leukemia, oral cancer, skin cancer, head and neck cancer, melanoma, renal cell carcinoma, bladder cancer, and prostate cancer [12-19]. Our study in CRC adds a new piece of evidence for the contribution of $E D N R B$ promoter hypermethylation to the risk of CRC. Our results further confirmed that DNA methylation in the promoter region played a key role in EDNRB transcription.

Some reports have focused on the correlation between EDNRB methylation and cancer clinical features [31-33]. Hypermethylation of the EDNRB gene in paired gastric

Table 2 Methylation status of EDNRB gene in CRC and normal tissues

\begin{tabular}{lllllll}
\hline & Total & $\mathbf{M}$ & $\mathbf{U}$ & $\mathbf{M} \%$ & $\mathbf{X}^{\mathbf{2}}$ & $\mathbf{p}$ value \\
\hline CRC cases & 42 & 39 & 3 & 92.86 & 11.091 & 0.001 \\
Controls & 42 & 25 & 17 & 59.52 & & \\
\hline
\end{tabular}

Table 3 Association between the EDNRB methylation in CRC serum and clinicopathologicalfeatures

\begin{tabular}{|c|c|c|c|c|c|c|}
\hline \multirow{2}{*}{ Characteristics } & & \multirow[b]{2}{*}{ n } & \multicolumn{2}{|c|}{$\begin{array}{c}\text { EDNRB } \\
\text { Methylation }\end{array}$} & \multirow[b]{2}{*}{$x^{2}$} & \multirow[b]{2}{*}{$p$ value } \\
\hline & & & $\bar{M}$ & $\mathrm{U}$ & & \\
\hline \multirow[t]{2}{*}{ Gender } & Male & 28 & 27 & 1 & 0.404 & 0.525 \\
\hline & Female & 14 & 12 & 2 & & \\
\hline \multirow[t]{2}{*}{ Age(year) } & $\leq 60$ & 16 & 16 & 0 & 0.629 & 0.428 \\
\hline & $>60$ & 26 & 23 & 3 & & \\
\hline \multirow[t]{2}{*}{ Stage } & $1 / 2$ & 21 & 18 & 3 & 1.436 & 0.231 \\
\hline & $3 / 4$ & 21 & 21 & 0 & & \\
\hline \multirow{2}{*}{$\begin{array}{l}\text { Lymph } \\
\text { metastasis }\end{array}$} & Yes & 21 & 21 & 0 & 1.436 & 0.231 \\
\hline & No & 21 & 18 & 3 & & \\
\hline \multirow{2}{*}{$\begin{array}{l}\text { Distant } \\
\text { metastasis }\end{array}$} & Yes & 8 & 8 & 0 & 0.012 & 0.913 \\
\hline & No & 34 & 31 & 3 & & \\
\hline \multirow[t]{2}{*}{ CEA } & $\geq 5.0 \mathrm{ng} / \mathrm{ml}$ & 15 & 14 & 1 & $<0.001$ & 1 \\
\hline & $<5.0 \mathrm{ng} / \mathrm{ml}$ & 27 & 25 & 2 & & \\
\hline \multirow[t]{2}{*}{ CA19-9 } & $\geq 37 \mathrm{U} / \mathrm{ml}$ & 9 & 8 & 1 & $<0.001$ & 1 \\
\hline & $<37 \mathrm{U} / \mathrm{ml}$ & 33 & 31 & 2 & & \\
\hline \multirow[t]{2}{*}{ Tumor location } & Colon & 26 & 24 & 2 & $<0.001$ & 1 \\
\hline & Rectum & 16 & 15 & 1 & & \\
\hline \multirow[t]{3}{*}{ Differentiation } & Poor & 10 & 10 & 0 & 0.091 & 0.763 \\
\hline & Moderate & 32 & 29 & 3 & & \\
\hline & Well & 0 & 0 & 0 & & \\
\hline \multirow[t]{2}{*}{ Tumor size } & $<5 \mathrm{~cm}$ & 28 & 25 & 3 & 0.404 & 0.525 \\
\hline & $\geq 5 \mathrm{~cm}$ & 14 & 14 & 0 & & \\
\hline \multirow{3}{*}{$\begin{array}{l}\text { Histological } \\
\text { classification }\end{array}$} & Adenocarcinoma & 40 & 37 & 3 & $<0.001$ & 1 \\
\hline & $\begin{array}{l}\text { Mucinous } \\
\text { adenocarcinoma }\end{array}$ & 2 & 2 & 0 & & \\
\hline & $\begin{array}{l}\text { Undifferentiated } \\
\text { carcinoma }\end{array}$ & 0 & 0 & 0 & & \\
\hline
\end{tabular}




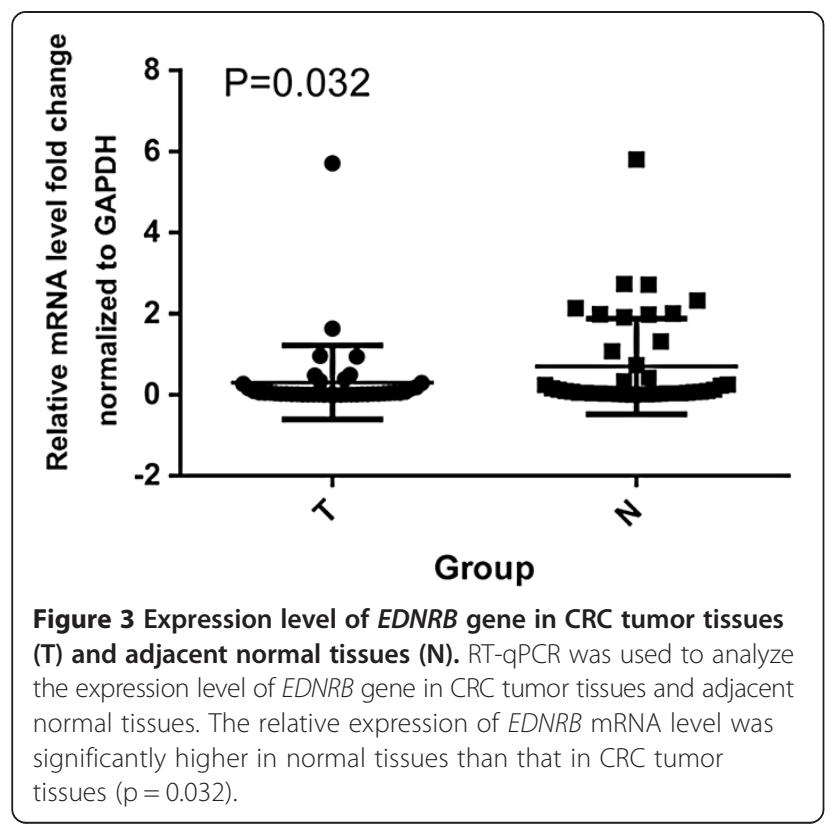

cancer tissues and adjacent normal tissues from $96 \mathrm{pa}-$ tients was detected [32]. EDNRB gene promoter methylation was shown to be associated with gastric cancer tumor invasion [32]. The extent of hypermethylation at CpG island in EDNRB gene was also evaluated in seven prostate cancer cell lines, normal prostate epithelial cells, normal prostate stromal cells, 73 primary prostate cancers, 91 metastatic prostate cancers, and 25 noncancerous prostate tissues [33]. EDNRB CpG island hypermethylation was shown to be correlated with pathological stage and Gleason score to a statistically significant extent in prostate cancer [33]. In the present study, we examined the relationship between the EDNRB methylation and the clinical features. Unfortunately, there was no significant relationship between EDNRB methylation or expression status and the clinical features. And this may be due to a lack of power in our samples. As a kind of glycoprotein produced by colorectal cancer tissue, CEA is a good tumor marker for judging efficacy, disease progression, and prognosis of colorectal cancer. CA19-9 was frequently increased in gastrointestinal tumors such as pancreatic cancer, gastric cancer, and colorectal cancer. CEA and CA19-9 are commonly and traditionally used in clinical colorectal cancer detection. Our study showed no correlation of EDNRB gene methylation status with the serum

Table 4 EDNRB mRNA expression levels in CRC and normal tissues*

\begin{tabular}{lllllll}
\hline & Total & Mean & SD & SE & t & p value \\
\hline CRC & 42 & 0.3074 & 0.91 & 0.14 & -2.214 & 0.032 \\
Control & 42 & 0.7041 & 1.18 & 0.18 & & \\
\hline
\end{tabular}

*: SD denotes standard deviation and SE denotes standard error.
Table 5 Correlation of EDNRB mRNA expression and clinicopathological parameters of colorectal cancer samples*

\begin{tabular}{|c|c|c|c|c|c|c|}
\hline \multirow[b]{2}{*}{ Characteristics } & & \multirow[b]{2}{*}{$\mathbf{n}$} & \multicolumn{3}{|c|}{$\begin{array}{l}E D N R B \text { expression } \\
\text { relative to GAPDH }\end{array}$} & \multirow[b]{2}{*}{$p$ value } \\
\hline & & & Mean & SD & SE & \\
\hline \multirow[t]{2}{*}{ Gender } & Male & 28 & 0.336 & 1.073 & 0.202 & 0.722 \\
\hline & Female & 14 & 0.250 & 0.480 & 0.130 & \\
\hline \multirow[t]{2}{*}{ Age (year) } & $\leq 60$ & 16 & 0.221 & 0.444 & 0.111 & 0.836 \\
\hline & $>60$ & 26 & 0.360 & 1.114 & 0.218 & \\
\hline \multirow[t]{2}{*}{ Stage } & $1 / 2$ & 21 & 0.143 & 0.233 & 0.051 & 0.792 \\
\hline & $3 / 4$ & 21 & 0.472 & 1.257 & 0.281 & \\
\hline \multirow{2}{*}{$\begin{array}{l}\text { Lymph } \\
\text { metastasis }\end{array}$} & Yes & 21 & 0.457 & 1.266 & 0.276 & 0.95 \\
\hline & No & 21 & 0.158 & 0.238 & 0.052 & \\
\hline \multirow{2}{*}{$\begin{array}{l}\text { Distant } \\
\text { metastasis }\end{array}$} & Yes & 8 & 0.781 & 1.996 & 0.706 & 0.741 \\
\hline & No & 34 & 0.196 & 0.351 & 0.060 & \\
\hline \multirow[t]{2}{*}{ CEA } & $\geq 5.0 \mathrm{ng} / \mathrm{ml}$ & 15 & 0.121 & 0.156 & 0.040 & 0.723 \\
\hline & $<5.0 \mathrm{ng} / \mathrm{ml}$ & 27 & 0.411 & 1.127 & 0.217 & \\
\hline \multirow[t]{2}{*}{ CA19-9 } & $\geq 37 \mathrm{U} / \mathrm{ml}$ & 9 & 0.102 & 0.153 & 0.051 & 0.526 \\
\hline & $<37 \mathrm{U} / \mathrm{ml}$ & 33 & 0.364 & 1.023 & 0.178 & \\
\hline \multirow[t]{2}{*}{ Tumor location } & Colon & 26 & 0.428 & 1.145 & 0.225 & 0.351 \\
\hline & Rectum & 16 & 0.112 & 0.156 & 0.039 & \\
\hline \multirow[t]{3}{*}{ Differentiation } & Poor & 10 & 0.719 & 1.779 & 0.558 & 0.494 \\
\hline & Moderate & 32 & 0.179 & 0.341 & 0.062 & \\
\hline & Well & 0 & / & / & / & \\
\hline \multirow[t]{2}{*}{ Tumor size } & $<5 \mathrm{~cm}$ & 28 & 0.386 & 1.102 & 0.208 & 0.968 \\
\hline & $\geq 5 \mathrm{~cm}$ & 14 & 0.151 & 0.248 & 0.066 & \\
\hline \multirow{3}{*}{$\begin{array}{l}\text { Histological } \\
\text { classification }\end{array}$} & Adenocarcinoma & 40 & 0.315 & 0.935 & 0.148 & 0.455 \\
\hline & $\begin{array}{l}\text { Mucinous } \\
\text { adenocarcinoma }\end{array}$ & 2 & 0.162 & 0.157 & 0.111 & \\
\hline & $\begin{array}{l}\text { Undifferentiated } \\
\text { carcinoma }\end{array}$ & 0 & / & / & / & \\
\hline
\end{tabular}

*: SD denotes standard deviation and SE denotes standard error.

levels of CEA and CA19-9. This might imply that aberrant $E D N R B$ methylation and conventional tumor markers could serve as complementary markers in the CRC diagnosis, although further work is needed to confirm our hypothesis.

In conclusion, we revealed a significant contribution of EDNRB hypermethylation to the risk of CRC. These findings may provide a new clue for detection and treatment of CRC. Future research is needed to determine the detailed mechanism of EDNRB gene in the risk of CRC.

\section{Abbreviations}

CRC: Colorectal cancer; EDNRB: Endothelin receptor type B; ETAR: Endothelin A receptor; ETBR: Endothelin B receptor; ETs: Endothelins. 


\section{Competing interest}

None of the authors have any commercial or other associations that might pose a conflict of interest. All authors are responsible for the content and writing of the paper.

\section{Authors' contributions}

MY and SD participated in research design. YH, HY and FC conducted experiments. LW, QL and LX performed data analysis. The manuscript was drafted by CC and SD, and critically reviewed and discussed with the other co-authors. All the authors read and approved the final manuscript.

\section{Authors' information}

Cheng Chen, Lingyan Wang, Qi Liao: co-first authors of this work.

\section{Acknowledgement}

The research was supported by the grants from the National Natural Science Foundation of China (31100919 and 81371469), Natural Science Foundation of Zhejiang Province (LR13H020003), K. C. Wong Magna Fund in Ningbo University, Ningbo Social Development Research Projects (2012C50032), and Scientific Innovation Team Project of Ningbo (2011B82014).

\section{Author details}

'Zhejiang Provincial Key Laboratory of Pathophysiology, School of Medicine, Ningbo University, Ningbo, Zhejiang 315211, China. ${ }^{2}$ The Affiliated Hospital, Ningbo University, Ningbo, Zhejiang 315000, China. ${ }^{3}$ Bank of Blood Products, Ningbo No.2 Hospital, Ningbo, Zhejiang 315010, China. ${ }^{4}$ Department of Neurosurgery, Ningbo First Hospital, Ningbo University, Ningbo, Zhejiang 315010, China.

Received: 22 October 2013 Accepted: 6 December 2013 Published: 10 December 2013

\section{References}

1. Migliore L, Migheli F, Spisni R, Coppede F: Genetics, cytogenetics, and epigenetics of colorectal cancer. J Biomed Biotechnol 2011, 2011:792362.

2. Siegel R, Ward E, Brawley O, Jemal A: Cancer statistics, 2011: the impact of eliminating socioeconomic and racial disparities on premature cancer deaths. CA Cancer J Clin 2011, 61(4):212-236.

3. Labianca R, Beretta GD, Kildani B, Milesi L, Merlin F, Mosconi S, et al: Colon cancer. Crit Rev Oncol Hematol 2010, 74(2):106-133.

4. Wangefjord S, Brandstedt J, Lindquist KE, Nodin B, Jirstrom K, Eberhard J: Associations of beta-catenin alterations and MSI screening status with expression of key cell cycle regulating proteins and survival from colorectal cancer. Diagn Pathol 2013, 8:10

5. Nodin $\mathrm{B}$, Johannesson $\mathrm{H}$, Wangefjord $\mathrm{S}, \mathrm{O}^{\prime}$ Connor DP, Lindquist $K \mathrm{E}_{\text {, Uhlen }}$ $M$, et al: Molecular correlates and prognostic significance of SATB1 expression in colorectal cancer. Diagn Pathol 2012, 7:115.

6. Dekanic A, Dintinjan RD, Budisavljevic I, Pecanic S, Butorac MZ, Jonjic N: Strong nuclear EGFR expression in colorectal carcinomas is associated with cyclinD1 but not with gene EGFR amplification. Diagn Pathol 2011, 6:108.

7. Jojima T, Suzuki K, Hirama N, Uchida K, Hattori Y: Glimepiride upregulates eNOS activity and inhibits cytokine-induced NF-kappaB activation through a phosphoinoside 3-kinase-Akt-dependent pathway. Diabetes Obes Metab 2009, 11(2):143-149.

8. Puffenberger EG, Hosoda K, Washington SS, Nakao K, deWit D, Yanagisawa $M$, et al: A missense mutation of the endothelin- $B$ receptor gene in multigenic Hirschsprung's disease. Cell 1994, 79(7):1257-1266.

9. Eberle J, Weitmann S, Thieck O, Pech H, Paul M, Orfanos CE: Downregulation of endothelin $B$ receptor in human melanoma cell lines parallel to differentiation genes. J Invest Dermatol 1999, 112(6):925-932.

10. Pao MM, Tsutsumi M, Liang G, Uzvolgyi E, Gonzales FA, Jones PA: The endothelin receptor $B$ (EDNRB) promoter displays heterogeneous, site specific methylation patterns in normal and tumor cells. Hum Mol Genet 2001, 10(9):903-910.

11. Yang AS, Doshi KD, Choi SW, Mason JB, Mannari RK, Gharybian V, et al: DNA methylation changes after 5-aza-2'-deoxycytidine therapy in patients with leukemia. Cancer Res 2006, 66(10):5495-5503.

12. Hsiao PC, Liu MC, Chen LM, Tsai CY, Wang YT, Chen J, et al: Promoter methylation of p16 and EDNRB gene in leukemia patients in Taiwan. Chin J Physiol 2008, 51(1):27-31.
13. Schussel J, Zhou XC, Zhang Z, Pattani K, Bermudez F, Jean-Charles G, et al: EDNRB and DCC salivary rinse hypermethylation has a similar performance as expert clinical examination in discrimination of oral cancer/ dysplasia versus benign lesions. Clin Cancer Res 2013, 19(12):3268-3275

14. Zhang M, Song F, Liang L, Nan H, Zhang J, Liu H, et al: Genome-wide association studies identify several new loci associated with pigmentation traits and skin cancer risk in European Americans. Hum Mol Genet 2013, 22(14):2948-2959.

15. Roh JL, Wang XV, Manola J, Sidransky D, Forastiere AA, Koch WM: Clinical correlates of promoter hypermethylation of four target genes in head and neck cancer: a cooperative group correlative study. Clin Cancer Res 2013, 19(9):2528-2540.

16. Cruz-Munoz W, Jaramillo ML, Man S, Xu P, Banville M, Collins C, et al: Roles for endothelin receptor $B$ and $B C L 2 A 1$ in spontaneous CNS metastasis of melanoma. Cancer Res 2012, 72(19):4909-4919.

17. Wuttig D, Zastrow S, Fussel S, Toma MI, Meinhardt M, Kalman K, et al: CD31, EDNRB and TSPAN7 are promising prognostic markers in clear-cell renal cell carcinoma revealed by genome-wide expression analyses of primary tumors and metastases. Int J Cancer 2012, 131(5):E693-E704.

18. Zuiverloon TC, Beukers W, van der Keur KA, Munoz JR, Bangma CH, Lingsma HF, et al: A methylation assay for the detection of non-muscle-invasive bladder cancer (NMIBC) recurrences in voided urine. BJU Int 2012, 109(6):941-948.

19. Vasiljevic N, Wu K, Brentnall AR, Kim DC, Thorat MA, Kudahetti SC, et al: Absolute quantitation of DNA methylation of 28 candidate genes in prostate cancer using pyrosequencing. Dis Markers 2011, 30(4):151-161.

20. de Freitas C-SM, Oliveira ZF, de Podesta JR, Gouvea SA, Von Zeidler SV, Louro ID: Methylation analysis of cancer-related genes in non-neoplastic cells from patients with oral squamous cell carcinoma. Mol Biol Rep 2011, 38(8):5435-5441.

21. Tang W, Li B, Tang J, Liu K, Qin J, Wu W, et al: Methylation analysis of EDNRB in human colon tissues of Hirschsprung's disease. Pediatr Surg Int 2013, 29(7):683-688.

22. Shen WJ, Dai DQ, Teng Y, Liu HB: Regulation of demethylation and reexpression of RASSF1A gene in gastric cancer cell lines by combined treatment of 5-Aza-CdR and NaB. World J Gastroenterol 2008, 14(4):595-600.

23. Du YY, Dai DQ, Yang Z: Role of RECK methylation in gastric cancer and its clinical significance. World J Gastroenterol 2010, 16(7):904-908.

24. Rizvi MM, Alam MS, Ali A, Mehdi SJ, Batra S, Mandal AK: Aberrant promoter methylation and inactivation of PTEN gene in cervical carcinoma from Indian population. J Cancer Res Clin Oncol 2011, 137(8):1255-1262.

25. Kang GH, Lee S, Kim JS, Jung HY: Profile of aberrant CpG island methylation along the multistep pathway of gastric carcinogenesis. Lab Invest 2003, 83(5):635-641.

26. Tost J: DNA methylation: an introduction to the biology and the disease-associated changes of a promising biomarker. Mol Biotechnol 2010, 44(1):71-81.

27. Davenport AP, Maguire JJ: Endothelin. Handb Exp Pharmacol 2006, 176(1):295-329.

28. Zhao BJ, Sun DG, Zhang M, Tan SN, Ma X: Identification of aberrant promoter methylation of EDNRB gene in esophageal squamous cell carcinoma. Dis Esophagus 2009, 22(1):55-61.

29. Lahav $\mathrm{R}$, Heffner $\mathrm{G}$, Patterson $\mathrm{PH}$ : An endothelin receptor $B$ antagonist inhibits growth and induces cell death in human melanoma cells in vitro and in vivo. Proc Natl Acad Sci USA 1999, 96(20):11496-11500.

30. Mallat A, Fouassier L, Preaux AM, Gal CS, Raufaste D, Rosenbaum J, et al: Growth inhibitory properties of endothelin-1 in human hepatic myofibroblastic Ito cells. An endothelin B receptor-mediated pathway. J Clin Invest 1995, 96(1):42-49.

31. Nelson J, Bagnato A, Battistini B, Nisen P: The endothelin axis: emerging role in cancer. Nat Rev Cancer 2003, 3(2):110-116.

32. Tao K, Wu C, Wu K, Li W, Han G, Shuai X, et al: Quantitative analysis of promoter methylation of the EDNRB gene in gastric cancer. Med Oncol 2012, 29(1):107-112.

33. Yegnasubramanian S, Kowalski J, Gonzalgo ML, Zahurak M, Piantadosi S, Walsh PC, et al: Hypermethylation of CpG islands in primary and metastatic human prostate cancer. Cancer Res 2004, 64(6):1975-1986.

doi:10.1186/1746-1596-8-199

Cite this article as: Chen et al:: Hypermethylation of EDNRB promoter contributes to the risk of colorectal cancer. Diagnostic Pathology 2013 8:199. 